\title{
Effects of reducing dietary protein on the expression of nutrition sensing genes (amino acid transporters) in weaned piglets"
}

\author{
Li WU ${ }^{\S}$, Liu-qin $\mathrm{HE}^{\S}$, Zhi-jie CUI, Gang LIU, Kang YAO, Fei WU, Jun LI, Tie-jun LI ${ }^{\dagger \star}$ \\ (Research Center of Healthy Breeding of Livestock and Poultry, Hunan Engineering and Research Center of Animal and Poultry Science, \\ Key Laboratory of Agro-ecological Processes in Subtropical Region, Institute of Subtropical Agriculture, \\ Chinese Academy of Sciences, Changsha 410125, China) \\ ${ }^{\dagger}$ E-mail: tjli@isa.ac.cn
}

Received Sept. 26, 2014; Revision accepted Mar. 12, 2015; Crosschecked Apr. 16, 2015

\begin{abstract}
The effects of crude protein (CP) levels in the diet on the mRNA expression of amino acid (AA) transporters were studied in a 45-d trial. Eighteen piglets with an initial body weight (BW) of $9.57 \mathrm{~kg}$ were assigned to three groups $(14 \%, 17 \%$, and $20 \%$ CP in the diet) in a completely randomized design (six replicates per treatment). Diets were supplemented with crystalline AA to achieve equal standardized ileal digestible contents of Lys, Met plus Cys, Thr, and Trp, and were provided ad libitum. After $45 \mathrm{~d}$, all piglets were slaughtered to collect small intestine samples. Compared with the values in the $14 \%$ CP group, the expressions of $A S C T 2,4 F 2 h c$, and $A T B^{0}$ mRNA in the jejunum were increased by $23.00 \%, 12.00 \%, 6.00 \%$ and $48.00 \%, 47.00 \%, 56.00 \%$ in the $17 \%$ and $20 \%$ CP groups, respectively. These results indicate that a $14 \%$ CP diet supplemented with crystalline AA may not transport enough AA into the body and maintain growth performance of piglets. However, a reduction of dietary $17 \% \mathrm{CP}$ may reduce the excretion of nitrogen into the environment while supporting the development of piglets. Therefore, the $17 \% \mathrm{CP}$ level is more suitable than $14 \%$ CP level.
\end{abstract}

Key words: Crude protein, Amino acid balance, Amino acid transporters doi:10.1631/jzus.B1400259 Document code: A

CLC number: S821.5

\section{Introduction}

It has been well documented that low crude protein (CP), amino acid (AA)-supplemented diets may reduce feed costs and nitrogen excretion (Kerr et al., 2003; Zarate et al., 2003; Fairbrother et al., 2005; Deng et al., 2007a; 2007b; Lallès et al., 2007; Hou et al., 2008; Kang et al., 2008; Yue and Qiao, 2008; Deng et al., 2009; Opapeju et al., 2009; Gallo et al., 2014; Gloaguen et al., 2014; Liu et al., 2014; Recktenwald et al., 2014). Therefore, the CP level in the diet of weaned pigs has been suggested to be one

\footnotetext{
ॠ Corresponding author

$\S$ The two authors contributed equally to this work

* Project supported by the National Basic Research Program (973) of China (No. 2013CB127301), the Natural Science Foundation of Hunan Province, China (No. 12JJ2014), and the National Natural Science Foundation of China (No. 31402088)

(D) ORCID: Peng LIAO, http://orcid.org/0000-0001-5740-7272

(C) Zhejiang University and Springer-Verlag Berlin Heidelberg 2015
}

of the main factors that affect their growth performance (Gallo et al., 2014), feed efficiency, and gastrointestinal health (Yin and Tan, 2010; Acciaioli et al., 2011). An increase in the entry of nutrients (e.g. dipeptides, tripeptides, arginine, lysine, and histidine) from the lumen of the small intestine into the enterocyte can enhance tissue protein synthesis and improve the efficiency of utilization of dietary nutrients, and it can selectively modulate the gene expression of AA transporters in intestinal cells (Wang et al., 2009). Some studies have reported that improving the efficiency of protein use and maintaining performance can be achieved by reducing the $\mathrm{CP}$ content of the diet while ensuring the AA balance (Kerr and Easter, 1995; Le Bellego and Noblet, 2002; Kerr et al., 2003; Opapeju et al., 2008; Gloaguen et al., 2014). However, Nyachoti et al. (2006) demonstrated that piglet performance may be impaired when dietary CP levels are reduced from 230 to 190 or $170 \mathrm{~g} / \mathrm{kg}$, as the AA 
deficiency may change the efficiency of AA absorption and transportation (Tuitoek et al., 1997; Tan et al., 2009; 2011; Gallo et al., 2014). The present study investigated the effects of reducing dietary $\mathrm{CP}$ while supplementing with essential AA on the gene expression of AA transporters in weaned piglets.

\section{Materials and methods}

\subsection{Animals and experimental treatment}

The experimental protocol was approved by the Protocol Management and Review Committee of the Institute of Subtropical Agriculture, Chinese Academy of Sciences (CAS). Pigs were cared for according to the guidelines of the Institute of Subtropical Agriculture on Animal Care, CAS.

Eighteen piglets (Duroc $\times$ Landrace $\times$ Yorkshire, female), from the experimental field of the animal observation station in southern center of China, were weaned at $28 \mathrm{~d}$ of age, but the experiment started after a 7-d adaptation period when the piglets were weighed to determine an initial mean body weight (BW; mean \pm standard deviation (SD), $(9.57 \pm 0.64) \mathrm{kg}$ ), and randomly assigned to three different groups (six pigs per group). Each of the groups was fed diets with different levels of CP $(14 \%, 17 \%$, and $20 \%)$, respectively. Their ingredients are shown in Tables 1 and 2. The dietary treatment met the National Research Council (NRC; 2012) nutrient specifications for 11 to $20 \mathrm{~kg}$ BW pigs. All of the animals were housed individually in cages, and had free access to feed and drinking water at all times throughout the experimental period.

\subsection{Relative quantification of mRNA expression of AA transporters}

Primers for the selected genes (Table 3) were designed using Oligo 6.0 software (Molecular Biology Insights, $\mathrm{CO}$, USA). After the quantity of complementary DNA (cDNA) was determined by a NanoDrop ${ }^{\circledR}$ ND-1000 (NanoDrop Technologies, Rockland, DE, USA), real-time quantitative polymerase chain reaction (PCR) analyses were performed on an ABI 7900HT Fast Real-Time PCR System (Applied Biosystems, CA, USA) with a total volume of $10 \mu \mathrm{l}$ containing $5 \mathrm{ng}$ of cDNA, $5 \mu \mathrm{l}$ SYBR Green mix, $0.2 \mu \mathrm{l}$ ROX Reference Dye $(50 \times)$, and $0.2 \mu \mathrm{l}$ each of the forward and reverse primers (Yao et al., 2012). The following protocol was used: (1) pre-denaturation $(30 \mathrm{~s}$ at $\left.95{ }^{\circ} \mathrm{C}\right)$; (2) amplification and quantification, repeated 40 cycles $\left(5 \mathrm{~s}\right.$ at $95^{\circ} \mathrm{C}, 30 \mathrm{~s}$ at $\left.60^{\circ} \mathrm{C}\right)$; and (3) a melting curve program (extension at $72^{\circ} \mathrm{C}$ ). $\beta$-Actin was used as an internal reference gene to normalize target gene transcript levels. The efficiency of the real-time reverse-transcription PCR was determined by the amplification of a dilution series of cDNA according to the equation $10^{(-1 / \text { slope })}$. Target mRNA

Table 1 Composition and nutrient levels of diets ${ }^{\mathrm{a}}$

\begin{tabular}{|c|c|c|c|}
\hline \multirow{2}{*}{ Component } & \multicolumn{3}{|c|}{ Content $(\%)^{b}$} \\
\hline & $14 \% \mathrm{CP}$ & $17 \% \mathrm{CP}$ & $20 \% \mathrm{CP}$ \\
\hline \multicolumn{4}{|l|}{ Ingredient } \\
\hline Corn & 71.80 & 66.50 & 63.70 \\
\hline Soybean meal & 13.40 & 18.80 & 19.80 \\
\hline Whey powder & 4.40 & 4.30 & 4.30 \\
\hline Fish meal & 1.50 & 4.00 & 9.00 \\
\hline Soybean oil & 4.10 & 2.60 & 0.80 \\
\hline Lys & 0.88 & 0.62 & 0.38 \\
\hline Met & 0.27 & 0.19 & 0.10 \\
\hline Thr & 0.33 & 0.21 & 0.09 \\
\hline Trp & 0.08 & 0.04 & 0.01 \\
\hline Calcium hydrophosphate & 1.15 & 0.74 & 0.00 \\
\hline Limestone & 0.79 & 0.70 & 0.52 \\
\hline Salt & 0.30 & 0.30 & 0.30 \\
\hline $1 \%$ premix compound $^{\mathrm{c}}$ & 1.00 & 1.00 & 1.00 \\
\hline Total & 100.00 & 100.00 & 100.00 \\
\hline \multicolumn{4}{|l|}{ Calculated nutrient content } \\
\hline $\mathrm{DE}(\mathrm{MJ} / \mathrm{kg})$ & 14.60 & 14.60 & 14.60 \\
\hline $\mathrm{CP}$ & 14.00 & 17.00 & 20.00 \\
\hline Total $\mathrm{Ca}$ & 0.70 & 0.71 & 0.69 \\
\hline Total P & 0.53 & 0.55 & 0.57 \\
\hline Arg & 0.75 & 0.91 & 1.09 \\
\hline His & 0.34 & 0.40 & 0.46 \\
\hline Ile & 0.49 & 0.60 & 0.70 \\
\hline Leu & 1.15 & 1.32 & 1.49 \\
\hline Lys & 1.23 & 1.23 & 1.23 \\
\hline Met+Cys & 0.68 & 0.68 & 0.68 \\
\hline Phe & 0.59 & 0.69 & 80 \\
\hline Thr & 0.73 & 0.73 & 0.73 \\
\hline Trp & 0.20 & 0.20 & 0.20 \\
\hline Val & 0.53 & 0.65 & 0.77 \\
\hline EAA/NEAA & 0.90 & 0.80 & 0.70 \\
\hline $\begin{array}{l}\text { Recommendation rate of } \\
\text { NRC (2012) }\end{array}$ & 0.80 & 0.80 & 0.80 \\
\hline
\end{tabular}

${ }^{a}$ Diets contain $14 \%, 17 \%$, and $20 \% \mathrm{CP}$, respectively, with appropriate crystalline AA supplementation. ${ }^{\mathrm{b}}$ The values are expressed as percentage (\%), except for digestible energy (DE; MJ/kg), essential AA (EAA)/nonessential AA (NEAA), and recommendation rate of NRC (2012). ${ }^{\mathrm{c}}$ Premix provided these amounts of vitamins and minerals per kilogram on an as-fed basis: vitamin A, $10800 \mathrm{IU}$; vitamin $\mathrm{D}_{3}$, $4000 \mathrm{IU}$; vitamin $\mathrm{E}$, $40 \mathrm{IU}$; vitamin $\mathrm{K}_{3}, 4 \mathrm{mg}$; vitamin $\mathrm{B}_{1}, 6 \mathrm{mg}$; vitamin $\mathrm{B}_{2}, 12 \mathrm{mg}$; vitamin $\mathrm{B}_{6}, 6 \mathrm{mg}$; vitamin $\mathrm{B}_{12}, 0.05 \mathrm{mg}$; biotin, $0.2 \mathrm{mg}$; folic acid, $2 \mathrm{mg}$; niacin, $50 \mathrm{mg}$; D-calcium pantothenate, $25 \mathrm{mg} ; \mathrm{Fe}, 100 \mathrm{mg}$ as ferrous sulfate; $\mathrm{Cu}, 150 \mathrm{mg}$ as copper sulphate; $\mathrm{Mn}, 40 \mathrm{mg}$ as manganese oxide; $\mathrm{Zn}, 100 \mathrm{mg}$ as zinc oxide; I, $0.5 \mathrm{mg}$ as potassium iodide; and $\mathrm{Se}, 0.3 \mathrm{mg}$ as sodium selenite 
Table 2 CP content and AA composition of feed ingredients used in formulating the experiment diets $^{\mathrm{a}}$

\begin{tabular}{|c|c|c|c|}
\hline \multirow{2}{*}{ Component } & \multicolumn{3}{|c|}{ Content $(\%)^{\mathrm{b}}$} \\
\hline & $14 \% \mathrm{CP}$ & $17 \% \mathrm{CP}$ & $20 \% \mathrm{CP}$ \\
\hline $\mathrm{CP}$ & 14.14 & 17.32 & 20.27 \\
\hline \multicolumn{4}{|l|}{ EAA } \\
\hline Arg & 0.71 & 0.93 & 1.09 \\
\hline His & 0.30 & 0.37 & 0.44 \\
\hline Ile & 0.46 & 0.60 & 0.71 \\
\hline Leu & 1.11 & 1.32 & 1.52 \\
\hline Lys & 1.26 & 1.25 & 1.26 \\
\hline Met & 0.41 & 0.42 & 0.40 \\
\hline Met+Cys & 0.63 & 0.65 & 0.62 \\
\hline Phe & 0.56 & 0.70 & 0.81 \\
\hline Thr & 0.76 & 0.75 & 0.76 \\
\hline $\operatorname{Trp}$ & 0.20 & 0.20 & 0.20 \\
\hline Tyr & 0.41 & 0.50 & 0.59 \\
\hline Val & 0.54 & 0.64 & 0.72 \\
\hline \multicolumn{4}{|l|}{ NEAA } \\
\hline Ala & 0.75 & 0.90 & 1.07 \\
\hline Asp & 1.15 & 1.49 & 1.76 \\
\hline Cys & 0.22 & 0.23 & 0.22 \\
\hline Glu & 2.28 & 2.78 & 3.15 \\
\hline Gly & 0.53 & 0.71 & 0.92 \\
\hline Pro & 0.90 & 1.04 & 1.17 \\
\hline Ser & 0.60 & 0.74 & 0.85 \\
\hline EAA & 6.29 & 7.18 & 7.91 \\
\hline NEAA & 6.84 & 8.40 & 9.74 \\
\hline EAA/NEAA & 0.92 & 0.85 & 0.81 \\
\hline
\end{tabular}

${ }^{\mathrm{a}}$ Diet contain $14 \%, 17 \%$, and $20 \% \mathrm{CP}$, respectively, with appropriate crystalline AA supplementation. ${ }^{\mathrm{b}}$ The values are expressed as percentage (\%), except for essential AA(EAA)/nonessential AA (NEAA) and $\beta$-actin mRNA were amplified with comparable efficiencies (Wang et al., 2009; He et al., 2013). Negative controls, in which cDNA was replaced by water, were also tested (Liu et al., 2012).

\subsection{Statistical analysis}

All data were subjected to a one-way analysis of variance (ANOVA; SAS Version 9.2) and data were presented as mean \pm standard error of the mean (SEM). Differences with $P$ values of $<0.05$ were considered to be statistically significant.

\section{Results}

\subsection{Growth performance of piglets fed diets with different levels of CP (internal data)}

The growth performance of weaned piglets fed diets with different $\mathrm{CP}$ levels is unpublished data. After the animals were fed different diets for $45 \mathrm{~d}$, significant differences were noted in the average daily gain (ADG) among the three groups $(P<0.01)$, and the $20 \%$ CP group had a significantly higher ADG than the other groups $(P<0.01)$. Average daily feed intake (ADFI) showed the same trend as ADG: the $20 \% \mathrm{CP}$ group had the highest ADFI and ADG, and 14\% CP group had the lowest ADFI and ADG. However, there was no significant difference in ADFI between the $17 \%$ and $20 \% \mathrm{CP}$ groups. While the $20 \% \mathrm{CP}$ group had the lowest feed to gain $(\mathrm{F} / \mathrm{G})$ ratio, there were no significant differences between the $14 \%$ and $17 \% \mathrm{CP}$ groups.

Table 3 Primers used for real-time PCR analysis

\begin{tabular}{|c|c|c|c|}
\hline Gene & Primer sequence $\left(5^{\prime} \rightarrow 3^{\prime}\right)$ & Length (bp) & Accession No. \\
\hline \multirow[t]{2}{*}{$A S C T 2$} & F: GCTTCCGAGAGCCAAGAACT & 152 & XM_003127238.3 \\
\hline & R: TCCTTAACGCCTGGAAGCTG & & \\
\hline \multirow[t]{2}{*}{$E A A C 1$} & F: GCTTCCTTCTTCCAGGGTCC & 148 & NM_001164649.1 \\
\hline & R: CTGGCCAATGTGGCTTGTTC & & \\
\hline \multirow[t]{2}{*}{$B^{0+} A T$} & F: GAGAGGTTTGGTCTTACTGCG & 96 & XM_003353809.2 \\
\hline & R: GCTATGACCAAGACGGAGCG & & \\
\hline \multirow[t]{2}{*}{$y^{+} L A T 1$} & F: TTTGTCTGACCGGCTCTTCC & 286 & XM_005666262.1 \\
\hline & R: GAGATCTCCTGCTGTCCTGG & & \\
\hline \multirow[t]{2}{*}{$4 F 2 h c$} & F: CTCGAACCCACCAAGGAC & 174 & NM_001110171.1 \\
\hline & R: GAGGTGAGACGGCACAGAG & & \\
\hline \multirow[t]{2}{*}{$A T B^{0}$} & F: TGGGGCATTTTGATTGCAGC & 238 & NM_001166042.1 \\
\hline & R: CTCCCCAGTCAGGGTATGGA & & \\
\hline \multirow[t]{2}{*}{$\beta$-Actin } & F: GGATGCAGAAGGAGATCACG & 130 & DQ845171 \\
\hline & R: ATCTGCTGGAAGGTGGACAG & & \\
\hline
\end{tabular}


Table 4 Effects of diets with different levels of CP on jejunal intestinal $A S C T 2, E A A C 1, B^{0+} A T, y^{+} L A T 1,4 F 2 h c$, and $A T B^{0}$ mRNA relative abundance in weaned piglets $(n=6)$

\begin{tabular}{|c|c|c|c|c|c|}
\hline \multirow{2}{*}{ mRNA } & \multicolumn{3}{|c|}{ Relative abundance } & \multirow{2}{*}{ SEM } & \multirow{2}{*}{$P$-value } \\
\hline & $14 \% \mathrm{CP}$ & $17 \% \mathrm{CP}$ & $20 \% \mathrm{CP}$ & & \\
\hline ASCT2 & 1.00 & 1.23 & 1.48 & 0.14 & 0.0340 \\
\hline$E A A C 1$ & 1.00 & 0.94 & 1.41 & 0.15 & 0.0270 \\
\hline$B^{0+} A T$ & 1.00 & 1.49 & 1.44 & 0.16 & 0.0160 \\
\hline$y^{+} L A T 1$ & 1.00 & 0.87 & 0.92 & 0.04 & 0.7369 \\
\hline $4 F 2 h c$ & 1.00 & 1.12 & 1.47 & 0.14 & 0.0846 \\
\hline$A T B^{0}$ & 1.00 & 1.06 & 1.56 & 0.18 & 0.0142 \\
\hline
\end{tabular}

Diets contain $14 \%, 17 \%$, and $20 \% \mathrm{CP}$, respectively, with appropriate crystalline AA supplementation

\section{2 mRNA expression of AA transporters}

Changes in the abundance of $A S C T 2, E A A C 1$, $B^{0+} A T, y^{+} L A T 1,4 F 2 h c$, and $A T B^{0}$ mRNA in the jejunum of the piglets are shown in Table 4 . While the abundance of $A S C T 2, E A A C 1, B^{0+} A T$, and $A T B^{0}$ mRNA significantly differed among the three groups $(P<0.05)$, there were no differences in the expression of $y^{+} L A T 1$ and $4 F 2 h c$ mRNA $(P>0.05)$. Compared with the values in the $14 \% \mathrm{CP}$ group, the expression of $A S C T 2,4 F 2 h c$, and $A T B^{0}$ mRNA in the jejunum was increased by $23.00 \%, 12.00 \%, 6.00 \%$ and $48.00 \%, 47.00 \%, 56.00 \%$ in the $17 \%$ and $20 \%$ CP groups, respectively. The $17 \% \mathrm{CP}$ group showed the lowest expression of EAACl mRNA, and the highest expression of $B^{0+} A T$ mRNA. Furthermore, while the expression of $y^{+} L A T 1$ in the $17 \%$ and $20 \% \mathrm{CP}$ groups was decreased by $13.00 \%$ and $8.00 \%$, respectively, compared with that in the $14 \% \mathrm{CP}$ group, there were no significant differences among the three groups $(P>0.05)$.

\section{Discussion}

AAs regulate key metabolic pathways that are crucial for the maintenance, health, and growth of animals (Wu, 1998; Hu et al., 2008). The absorption of AA requires many transporter systems that differ with respect to their substrate specificity and driving force (Wang et al., 2009). It has been reported that some genes (such as $A S C T 2, E A A C 1, B^{0+} A T, y^{+} L A T 1$, $4 F 2 h c$, and $A T B^{\circ}$ ) that are involved in the control of growth or AA metabolism are regulated by AA availability (Wu, 1998; Lallès et al., 2007; Zhang et al., 2012; Abdulhussein and Wallace, 2014). In our study, we found that, with an increase in the dietary $\mathrm{CP}$ level, the expression of AA transporter genes ( $A S C T 2, E A A C 1, B^{0+} A T, 4 F 2 h c$, and $A T B^{\circ}$ ) tended to increase, while an opposite trend was seen related to the abundance of $y^{+} L A T 1$ mRNA. A possible reason was that $y^{+} L A T 1$ and $E A A C 1$ have differential expression in our study because the diets with different CP levels related with absorption in piglets. The transport of AA in the small intestine is critical for the supply of AA to all tissues and the homeostasis of serum AA levels (Zhang et al., 2012). Since dietary $\mathrm{CP}$ can provide an ideal AA level, the genes of AA transporters that regulate protein metabolism in piglets should be more activated. The present results indicate that the expression of $A S C T 2, E A A C 1, B^{0+} A T$, and $A T B^{\circ}$ mRNA in the jejunum was influenced by dietary CP levels. Our results regarding the expression of $y^{+} L A T 1$ mRNA were similar to those of $\mathrm{He}$ et al. (2013). Under conditions of nutritional stress, the expression of some AA transporters $\left(y^{+} L A T 1\right)$ may be increased to maintain normal growth of animals under adverse conditions (He et al., 2013). Skalli et al. (2014) suggest that dietary protein levels regulate the expression of AA transporter genes by a complex regulatory system, which may also affect the energy balance and endocrine system. AAs and hormones can play an important role in the regulation of gene expression. Overall, the use of low-CP (14\%) AA-supplemented diets in piglets may decrease the transport capacity of AA in the small intestine. However, the absorption and transport of $\mathrm{AA}$ is a complex physiological process that is influenced by many factors (Wang et al., 2009; He et al., 2013; 
Zhang et al., 2013; Chen et al., 2014), including the dietary CP level and the AA balance. Thus, the transport of these nutrients is a key regulatory step in the use of dietary protein by weaned piglets. An excess decrease in dietary $\mathrm{CP}$ with AA supplementation resulted in significant reductions in the expression of AA transporter genes in the jejunum. This result suggests that there is an appropriate range within which $\mathrm{CP}$ in the diet may be reduced, and any further decrease may dramatically reduce the efficiency of energy and AA utilization in the small intestine (Jensen, 1998). This understanding may also make it possible to increase productivity and reduce the impact of livestock on the environment (Franklin et al., 2002). While this finding has important practical implications, further research will be required to elucidate the underlying mechanisms.

\section{Acknowledgements}

We apologize to colleagues whose work was not cited here due to our oversight.

\section{Compliance with ethics guidelines}

Li WU, Liu-qin HE, Zhi-jie CUI, Gang LIU, Kang YAO, Fei WU, Jun LI, and Tie-jun LI declare that they have no conflict of interest.

All institutional and national guidelines for the care and use of laboratory animals were followed.

\section{References}

Abdulhussein, A.A., Wallace, H.M., 2014. Polyamines and membrane transporters. Amino Acids, 46(3):655-660. [doi:10.1007/s00726-013-1553-6]

Acciaioli, A., Sirtori, F., Pianaccioli, L., et al., 2011. Comparison of total tract digestibility and nitrogen balance between Cinta Senese and Large White pigs fed on different levels of dietary crude protein. Anim. Feed Sci. Tech., 169(1-2):134-139. [doi:10.1016/j.anifeedsci.2011. 05.009]

Chen, G., Zhang, J., Zhang, Y.Z., et al., 2014. Oral MSG administration alters hepatic expression of genes for lipid and nitrogen metabolism in suckling piglets. Amino Acids, 46(1):245-250. [doi:10.1007/s00726-013-1615-9]

Deng, D., Li, A.K., Chu, W.Y., et al., 2007a. Growth performance and metabolic responses in barrows fed lowprotein diets supplemented with essential amino acids. Livest. Sci., 109(1-3):224-227. [doi:10.1016/j.livsci.2007. 01.104]

Deng, D., Huang, R.L., Li, T.J., et al., 2007b. Nitrogen balance in barrows fed low-protein diets supplemented with es- sential amino acids. Livest. Sci., 109(1-3):220-223. [doi:10.1016/j.livsci.2007.01.122]

Deng, D., Yao, K., Chu, W.Y., et al., 2009. Impaired translation initiation activation and reduced protein synthesis in weaned piglets fed a low-protein diet. J. Nutr. Biochem., 20(7):544-552. [doi:10.1016/j.jnutbio.2008.05.014]

Fairbrother, J.M., Nadeau, E., Gyles, C.L., 2005. Escherichia coli in postweaning diarrhea in pigs: an update on bacterial types, pathogenesis, and prevention strategies. Anim. Health Res. Rev., 6(1):17-39. [doi:10.1079/AHR2005105]

Franklin, M.A., Mathew, A.G., Vickers, J.R., et al., 2002. Characterization of microbial populations and volatile fatty acid concentrations in the jejunum, ileum, and cecum of pigs weaned at 17 vs 24 days of age. J. Anim. Sci., 80(11):2904-2910.

Gallo, L., Monta, G.D., Carraro, L., et al., 2014. Growth performance of heavy pigs fed restrictively diets with decreasing crude protein and indispensable amino acids content. Livest. Sci., 161:130-138. [doi:10.1016/j.livsci. 2013.12.027]

Gloaguen, M., Le Floc'h, N., Corrent, E., et al., 2014. The use of free amino acids allows formulating very low crude protein diets for piglets. J. Anim. Sci., 92(2):637-644. [doi:10.2527/jas.2013-6514]

He, L.Q., Yang, H.S., Hou, Y.Q., et al., 2013. Effects of dietary L-lysine intake on the intestinal mucosa and expression of cat genes in weaned piglets. Amino Acids, 45(2): 383-391. [doi:10.1007/s00726-013-1514-0]

Hou, Z.P., Yin, Y.L., Huang, R.L., et al., 2008. Rice protein concentrate partially replaces dried whey in the diet for early-weaned piglets and improves their growth performance. J. Sci. Food Agric., 88(7):1187-1193. [doi:10.1002/ jsfa.3196]

Hu, C.A., Khalil, S., Zhaorigetu, S., et al., 2008. Human $\Delta^{1}$-pyrroline-5-carboxylate synthase: function and regulation. Amino Acids, 35(4):665-672. [doi:10.1007/s00726008-0075-0]

Jensen, B.B., 1998. The impact of feed additives on the microbial ecology of the gut in young pigs. J. Anim. Feed Sci., 7:45-64.

Kang, P., Yin, Y.L., Ruan, Z., et al., 2008. Effect of replacement of lactose with partially hydrolysed rice syrup on small intestine development in weaned pigs from 7 to 21 days. J. Sci. Food Agric., 88(11):1932-1938. [doi:10. 1002/jsfa.3298]

Kerr, B.J., Easter, R.A., 1995. Effects of feeding reduced protein, amino acid-supplemented diets on nitrogen and energy-balance in grower pigs. J. Anim. Sci., 73(10): 3000-3008.

Kerr, B.J., Southern, L.L., Bidner, T.D., et al., 2003. Influence of dietary protein level, amino acid supplementation, and dietary energy levels on growing-finishing pig performance and carcass composition. J. Anim. Sci., 81(12): 3075-3087. 
Lallès, J.P., Bosi, P., Smidt, H., et al., 2007. Nutritional management of gut health in pigs around weaning. Proc. Nutr. Soc., 66(2):260-268. [doi:10.1017/S0029665107 005484]

Le Bellego, L., Noblet, J., 2002. Performance and utilization of dietary energy and amino acids in piglets fed low protein diets. Livest. Prod. Sci., 76(1-2):45-58. [doi:10.1016/ S0301-6226(02)00008-8]

Liu, M.B., Li, X.L., Liu, Y., et al., 2014. Detection of crude protein, crude starch, and amylose for rice by hyperspectral reflectance. Spectrosc. Lett., 47(2):101-106. [doi:10. 1080/00387010.2013.779283]

Liu, X.D., Wu, X., Yin, Y.L., et al., 2012. Effects of dietary L-arginine or $\mathrm{N}$-carbamylglutamate supplementation during late gestation of sows on the miR-15b/16, miR-221/222, VEGFA and eNOS expression in umbilical vein. Amino Acids, 42(6):2111-2119. [doi:10.1007/ s00726-011-0948-5]

Nyachoti, C.M., Omogbenigun, F.O., Rademacher, M., et al., 2006. Performance responses and indicators of gastrointestinal health in early-weaned pigs fed low-protein amino acid-supplemented diets. J. Anim. Sci., 84(1): 125-134.

Opapeju, F.O., Rademacher, M., Blank, G., et al., 2008. Effect of low-protein amino acid-supplemented diets on the growth performance, gut morphology, organ weights and digesta characteristics of weaned pigs. Animal, 2(10): 1457-1464. [doi:10.1017/S175173110800270X]

Opapeju, F.O., Rademacher, M., Nyachoti, C.M., 2009. Effect of dietary crude protein level on jejunal brush border enzyme activities in weaned pigs. Arch. Anim. Nutr., 63(6):455-466. [doi:10.1080/17450390903299133]

Recktenwald, E.B., Ross, D.A., Fessenden, S.W., et al., 2014. Urea-N recycling in lactating dairy cows fed diets with 2 different levels of dietary crude protein and starch with or without monensin. J. Dairy Sci., 97(3):1611-1622. [doi:10.3168/jds.2013-7162]

Skalli, A., Zambonino-Infante, J.L., Kotzamanis, Y., et al., 2014. Peptide molecular weight, distribution of soluble protein fraction affects growth performance and quality in European sea bass (Dicentracrchus labrax) larvae. Aquacul. Nutr., 20(2):118-131. [doi:10.1111/anu.12058]

Tan, B., Yin, Y., Liu, Z., et al., 2009. Dietary L-arginine supplementation increases muscle gain and reduces body fat mass in growing-finishing pigs. Amino Acids, 37(1): 169-175. [doi:10.1007/s00726-008-0148-0]

Tan, B., Yin, Y., Liu, Z., et al., 2011. Dietary L-arginine supplementation differentially regulates expression of lipidmetabolic genes in porcine adipose tissue and skeletal muscle. J. Nutr. Biochem., 22(5):441-445. [doi:10.1016/ j.jnutbio.2010.03.012]

Tuitoek, K., Young, L.G., de Lange, C.F., et al., 1997. The effect of reducing excess dietary amino acids on growing- finishing pig performance: an elevation of the ideal protein concept. J. Anim. Sci., 75(6):1575-1583.

Wang, W., Gu, W., Tang, X., et al., 2009. Molecular cloning, tissue distribution and ontogenetic expression of the amino acid transporter $\mathrm{b}^{0,+}$ cDNA in the small intestine of Tibetan suckling piglets. Comp. Biochem. Physiol. B Biochem. Mol. Biol., 154(1):157-164. [doi:10.1016/j.cbpb. 2009.05.014]

Wu, G., 1998. Intestinal mucosal amino acid catabolism. $J$. Nutr., 128(8):1249-1252.

Yao, K., Yin, Y., Li, X., et al., 2012. Alpha-ketoglutarate inhibits glutamine degradation and enhances protein synthesis in intestinal porcine epithelial cells. Amino Acids, 42(6):2491-2500. [doi:10.1007/s00726-011-1060-6]

Yin, Y.L., Tan, B., 2010. Manipulation of dietary nitrogen, amino acids and phosphorus to reduce environmental impact of swine production and enhance animal health. $J$. Food Agric. Environ., 8(3-4):447-462.

Yue, L.Y., Qiao, S.Y., 2008. Effects of low-protein diets supplemented with crystalline amino acids on performance and intestinal development in piglets over the first 2 weeks after weaning. Livest. Sci., 115(2-3):144-152. [doi:10.1016/j.livsci.2007.06.018]

Zarate, A.J., Moran, E.T., Burnham, D.J., 2003. Reducing crude protein and increasing limiting essential amino acid levels with summer-reared, slow- and fast-feathering broilers. J. Appl. Poultry Res., 12(2):160-168. [doi:10. 1093/japr/12.2.160]

Zhang, J., Yin, Y.L., He, Q.H., et al., 2012. Effects of MSG supplementation on free amino acids in plasma of growingfinishing pigs. J. Food Agric. Environ., 10(3-4):600-605.

Zhang, J., Yin, Y.L., Shu, X.G., et al., 2013. Oral administration of MSG increases expression of glutamate receptors and transporters in the gastrointestinal tract of young piglets. Amino Acids, 45(5):1169-1177. [doi:10.1007/ s00726-013-1573-2]

\section{中文概要} 透: 降低日粮粗蛋白水平对断奶仔猪营养感受体基因
(氨基酸转运载体) 表达的影响

目 的: 验证日粮中粗蛋白质浓度对断奶仔猪氨基酸转运 载体的影响效应。

创新点: 从营养物质感应体的角度分析采用低氮日粮的可 行性, 并探索营养限制对营养转运体的影响及它 们间的相互作用。

方 法: 十八头初始体重 9.57 公斤的断奶仔猪被随机分为 三组 (每组 6 个重复), 分别饲喂含有 $14 \% 、 17 \%$ 和 $20 \%$ 的粗蛋白日粮 45 天。按照理想蛋白质模 
型, 日粮分别添加赖氨酸、蛋氨酸 + 半胱氨酸、 苏氨酸和色氨酸来满足断奶仔猪的需要, 整个试 验期自由采食。试验结束后, 屠宰仔猪并采集小 肠样品。与 $14 \%$ 粗蛋白组相比, 空肠中 ASCT2、 $4 F 2 h c$ 和 $A T B^{0}$ mRNA 表达在 $17 \%$ 和 $20 \%$ 粗蛋白 水平组分别上升 $23.00 \% 、 12.00 \% 、 6.00 \%$ 和 $48.00 \% 、 47.00 \% 、 56.00 \%$ 。
结 论: 结果表明, $14 \%$ 粗蛋白水平组外源添加合成氨基 酸并不能促进氨基酸转运载体增加氨基酸的吸 收来满足断奶仔猪的生长性能。然而, $17 \%$ 粗蛋 白水平组可以减少氮排放到环境中, 同时又能满 足此阶段断奶仔猪的生长发育。因此, $17 \%$ 粗蛋 白水平组对这个阶段断奶仔猪最合适。

关键词: 粗蛋白; 氨基酸平衡; 氨基酸转运载体 